\title{
PENINGKATAN KEMAMPUAN MEMBACA HURUF HIJAIYAH MELALUI KARTU HURUF HIJAIYAH DI PAUD
}

\author{
Alucyana $^{1}$, Raihana $^{2}$, Dian Tri Utami ${ }^{3}$ \\ 1,2,3 Prodi Pendidikan Islam Anak Usia Dini, Fakultas Agama Islam Universitas Islam Riau \\ J1. Kaharuddin Nasution No. 113 Marpoyan Damai Pekanbaru, Provinsi Riau, Indonesia \\ Email: raihanarere@gmail.com
}

\begin{abstract}
Early age is often referred to as the golden age (Golden Age) during which all aspects of development in children experience very significant development and this is the right time for parents and teachers to lay the foundations of the skills they will develop. To introduce letters hijaiyah to children after early childhood in some PAUD institutions are still applying conventional methods by using the book Iqro '. Introduction of hijaiyah letters can be varied by using hijaiyah letter cards. Learning model in the conventional way. This study wants to see the effectiveness of the use of hijaiyah letters in improving the ability to read hijaiyah letters in early childhood in PAUD. The research method used in this study is Classroom Action Research $(C A R)$. The results showed that the ability to read hijaiyah letters in B2 class PAUD Arrahma Siak Hulu increased by using hijaiyah letter media development. Evidenced by the results of cycle 1 that 50\% complete reading hijaiyah letters while in increased to $93.75 \%$
\end{abstract}

Keywords: Cards, Hijaiyah Letters, Reading, Early Childhood

\begin{abstract}
ABSTRAK
Usia dini sering disebut sebagai usia keemasan (Golden Age) dimana pada masa tersebut seluruh aspek perkembangan pada anak mengalami perkembangan sangat signifikan dan ini adalah saat yang tepat bagi orangtua dan guru meletakkan dasar-dasar ketrampilan yang akan mereka kembangkan. Untuk mengenalkan huruf hijaiyah kepada anak usai dini pada beberapa lembaga PAUD masih menerapkan metode konvensional yaitu dengan menggunakan buku Iqro'. Pengenalan huruf hijaiyah dapat divariasikan dengan menggunakan media kartu huruf hijaiyah. Model pembelajaran dengan cara konvensional. Penelitian ini ingin melihat efektifitas penggunaan kartu huruf hijaiyah dalam peningkatan kemampuan membaca huruf hijaiyah pada anak usia dini di PAUD. Metode Penelitian yang digunakan dalam penelitian ini adalah Penelitian Tindakan Kelas (PTK). Hasil penelitian menunjukkan bahwa kemampuan membaca huruf hijaiyah di kelas B2 PAUD Arrahma Siak Hulu terjadi peningkatan dengan menggunakan media kartu huruf hijaiyah. Terbukti dengan hasil siklus 1 yang 50\% tuntas membaca huruf hijaiyah sedangkan di siklus 2 meningkat menjadi 93,75\%.
\end{abstract}

Kata Kunci : Kartu, Huruf Hijaiyah, membaca, Anak Usia Dini.

FIRST RECEIVED:

13 February 2020
REVISED: 29 April 2020
ACCEPTED: 30 April 2020
PUBLISHED: 30 April 2020 


\section{PENDAHULUAN}

Kualitas seseorang dapat dilihat dan dinilai melalui kemampuan membacanya. Dalam pengertian umum kegiatan yang dilakukan dalam bentuk menelusuri, memahami hingga mengenali berbagai simbol bisa diartikan sebagai kegiatan membaca. Bentuk dari simbol yang bisa digunakan berupa rangkaian huruf-huruf dalam satu tulisan, bacaan dan juga gambar.

Untuk membangun manusia yang memiliki kemampuan membaca yang bagus maka diperlukan didikan dari usia dini. Membiasakan anak untuk membaca merupakan sebuah kegiatan positif yang harus didukung oleh orang tua dan lingkungan. Selain itu diperlukan juga media, yang dapat membantu dan mengasah kemampuan anak dengan cara yang lebih santai, tanpa tekanan dan tentunya menyenangkan bagi anak itu sendiri.

Pembentukan kepribadian manusia secara menyeluruh pertama kali dilakukan ketika seseorang masih berusia dini, karena pada masa usia dini masih sangat mudah diarahkan dan dilaksanakan sebagai dasar perkembangan manusia selanjutnya. Anak adalah individu kecil yang memiliki karakteristik yang sangat unik sesuai dengan tahapan perkembangannya.

Fase perkembangan anak usia dini memegang peranan penting sebagai dasar pembentukan karakter dan kepribadian manusia. Pembentukan karakter dan kepribadian yang utuh mencakup pembentukan karakter, budi pekerti, ceria, terampil, cerdas, dan bertakwa kepada Allah swt. Anak merupakan individu yang tumbuh dalam keadaan unik dalam pembentukan karakter tersebut. Keunikan pada anak tampak pada setiap fase perkembangannya.

Fase anak usia dini dikenal sebagai fase Golden Age. Makna fase tersebut anak mengalami masa peka dalam menerima suatu stimulus. Pada masa pekanya tersebut anak juga mengalami kematangan dalam hal perkembangan fisik dan psikis. Sehingga pada saat fase ini anak dianggap sudah siap untuk menerima timbal balik dan melaksanakan semua tugas-tugas perkembangan yang akan diterapkan dan muncul pada prilaku kesehariannya.

Bentuk stimulus pada anak umumnya berasal dari orang terdekat. Oleh karena itu, idealnya cara belajar anak didesain dengan cara yang menyenangkan dan tanpa tekanan. Fase atau masa keemasan pada anak (golden age) merupakan masa paling tepat mengasah setiap aspek kemampuan yang dimiliki oleh anak, salah satu kemampuan tersebut adalah kemampuan pengembangan bahasa.

Bahasa merupakan kemampuan untuk berkomunikasi dengan orang lain (Yusuf, S., 2007). Bahasa merupakan sarana penting bagi perkembangan dan kehidupan anak yang harus disesuaikan dengan situasi dan kondisi sang anak. Konsep "bermain sambil belajar" perlu dilaksanakan secara inovatif dan kreatif, agar anak merasa suatu permainan yang menyenangkan. Pada umumnya anak-anak sangat menikmati permainan dan akan terus bermain dimanapun mereka memiliki kesempatan untuk bermain.

Dhieni (dalam Rahmawati, R., 2013) mengatakan karakteristik kemampuan bahasa anak usia taman kanak-kanak (usia 5-6 tahun) adalah, anak sudah mampu mengucapkan lebih dari 2500 kosa kata, lingkup kosa kata yang diucapkan anak menyangkut: warna, 
ukuran, bentuk, rasa, bau, kecantikan, kecepatan, suhu, perbedaan, perbandingan jarak, permukaan (kasar, halus), sudah dapat melakukan peran sebagai pendengar yang baik serta dapat berpartisipasi dalam suatu percakapan.

Kemampuan lain yang dimiliki oleh anak yaitu anak dapat menggunakan kata ganti saya dalam berkomunikasi, memiliki berbagai perbendaharaan kata kerja, kata sifat, kata keadaan, kata tanya dan kata sambung, menunjukkan pengertian dan pemahaman akan sesuatu hal, mampu mengungkapkan fikiran, perasaan dan tindakan dengan mempergunakan kalimat-kalimat sederhana dan simpel, selain itu gambar bagi anak juga bisa menjadi media untuk anak mampu membaca dan menangkap sesuatu hal..

Bahasa memiliki manfaat yang sangat banyak bagi perkembangan, peningkatan intelektual dan keterampilan bahasa anak, selain anak dapat menjalin hubungan dengan orang lain, anak juga bisa saling berbagi pengalaman, serta dapat meningkatkan intelektualnya karena dengan bahasa atau kata-kata yang dikeluarkan dari mulut seseorang juga dapat dinilai memiliki intelektualitas yang bagus atau tidak.

Melalui bahasa juga anak dapat mengungkapkan apa yang di fikirkannya tentang suatu hal kepada orang lain. Anak yang mengajak orang lain berbicara akan lebih mudah mengerti maksud dari pembicaraan si anak dibanding anak yang ketika berkomunikasi menggunakan gerakan. Bagi anak yang mengalami hal tersebut adalah merupakan masa dimana anak harus dibina dan dikembangkan agar anak dapat merasakan manfaat dari kemampuan bahasanya secara optimal. Bimbingan dan arahan yang tidak tepat dan bahkan salah dari orang tua dan guru di sekolah akan mengakibatkan perkembangan bahasa anak tidak sesuai dengan yang diharapkan.

Menurut Musfiroh, T. (2005) Ada 2 bentuk bahasa jika dilihat secara umum yaitu, 1) bahasa lisan, 2) bahasa tulisan. Penggunaan kata-kata yang diucapkan secara efektif merupakan salah satu kemampuan dari bahasa lisan. Anak yang cerdas dalam penggunaan bahasa biasanya akan meyukai kegiatan bermain yang menjembatani kebutuhan anak tersebut untuk mulai berbicara, bercerita melalui negosiasi dan juga beberapa kegiatan yang memperlihatkan dan menunjukkan perasaan dan fikiran dalam kosakata.

Dalam buku Dhieni, dkk. (2014) ada dua kemampuan yang disebutkan dalam bahasa reseptif yaitu pertama, kemampuan mendengar dan kedua, kemampuan membaca. Dua hal ini sangat penting bagi anak karena digunakan sebagai media komunikasi untuk memperoleh informasi baru. Anak memperoleh informasi pada awalnya melalui mendengar dan mengamati. Berikutnya, anak mulai belajar membaca supaya mendapatkan informasi baru tersebut melalui tulisan yang dipelajari. Jadi untuk memahami sebuah tulisan pada umumnya selalu dihubungkan dengan kemampuan seseorang dalam membaca.

Menurut Yusuf, S. (2007) aspek atau bentuk bahasa yang terpenting untuk dikembangkan pada anak usia dini adalah kemampuan membaca. Hubungan antara huruf dan bunyi mengeluarkan sebuah kalimat yang merupakan bentuk dari membaca. Saat anak membaca, pemahaman awal anak hanya dalam sebatas konsep pengetahuan dan pengalaman saja sehingga membaca termasuk 
salah satu proses pemahaman (comprehending process) yang menjadi bagian dalam tugas perkembangan bahasa yang harus dijalani dan dilalui oleh anak. Pemahaman yang dimaksud memahami makna ucapan orang lain.

Dhieni, dkk. (2015) membagi 4 pendekatan dalam metode pengembangan membaca pada anak usia dini, teridri dari yaitu: 1) Pendekatan pengalaman bahasa, berupa mengambil kata-kata anak sendiri untuk membantu anak belajar membaca. Kata-kata yang digunakan antara lain seperti penjelasan suatu gambar, sebuah cerita pendek. Tujuan dilakukan pendekatan ini adalah untuk membantu anak dalam memahami bahwa kata-kata yang tertulis berupa komunikasi yang bermakna. 2) Fonik, pendekatan fonik menggunakan huruf alfabet sebagai keunggulan metode ini, anak mendengarkan lalu mengikuti guru membaca huruf alfabet kemudian anak menulis katakata dengan merangkai huruf-huruf tersebut. 3) Lihat dan katakan, salah satu metode yang paling efektif digunakan yaitu anak melihat dulu huruf lalu mendengarkan huruf itu dibaca dan kemudian mengulangi mengucapkan kata yang didengar. 4) Metode pendukung konteks, adalah metode yang menggunakan buku yang benar-benar menarik bagi mereka, menarik dari segi tulisan dan gambar yang ditampilkan. Sehingga ketika anak belajar menbaca tidak terlihat membosankan dan menarik minat anak dalam membaca.

Sementara itu menurut Jamaris, M. (2006) ada tahap-tahap kemampuan membaca pada anak usia dini yaitu: 1) Tahap timbulnya kesadaran terhadap tulisan, pada tahap ini anak mulai belajar menggunakan buku dan mulai menyadari bahwa buku itu penting, melihat dan membolak balik buku dan kadang anak membawa buku kesukaanya, 2) Tahap membaca gambar, pada tahap ini anak sudah menyadari bahwa buku memiliki ciri khas yang khusus, seperti gambar-gambar yang menarik dan bentuk tulisan serta warna yang juga menarik, 3) tahap pengenalan bacaan, pada tahap ini anak usia dini di taman kanakkanan telah dapat menggunakan tiga sistem bahasa seperti fonem (bunyi huruf), semantik (arti kata) dan sintatik (aturan kata atau kalimat) dan 4) tahap membaca lancar. Pada tahap ini kemampuan membaca anak sudah lancar dan anak membaca dengan berbagai jenis buku yang berbeda serta bahan-bahan yang langsung berhubungan kehidupan sehari-hari.

Anak yang mampu membaca lebih awal selalu ditandai dengan memiliki kemampuan pengenalan huruf yang dalam. Anak yang mengenal huruf cenderung memiliki kesempatan dapat membaca lebih baik daripada anak yang belum mengenal huruf (Suyanto, S., \& Novidha, F., 2008).

Mengenalkan huruf kepada anak merupakan sesuatu hal yang penting dengan tujuan dasar yaitu bagaimana anak dapat membaca dan menulis melalui proses yang benar. Perkenalan anak pada huruf bisa diawali dengan mendengarkan bunyi dan bentuk hurufnya. Salah satu huruf yang bisa diperkenalkan pada anak adalah huruf hijaiyah.

Pengenalan huruf hijaiyah pada anak usia dini dapat dimulai dari huruf penyusun alphabet arab. Adapun langkah membaca pada anak dapat dilakukan dengan membaca cerita-cerita khayalan, membaca dongeng atau fantasi sampai pada membaca lancar. 
Salah satu pembelajaran bahasa pada anak PAUD yaitu melalui pengenalan huruf hijaiyah. Menurut Rasyid (dalam Iqomah, F., 2018) pembelajaran bahasa pada anak tersebut dimulai dari mengenali dahulu kemampuan anak apakah anak sudah memahami dan mengenal huruf-huruf hijaiyah. Huruf-huruf yang tersusun dalam bentuk tulisan perlu diperkenalkan pada anak untuk membantu proses membaca anak menjadi lebih lancar. Agar anak mampu membaca dengan baik makan anak dapat dirangsang dengan cara melatih indera pendengarannya untuk mendengarkan bunyi huruf, kata-kata tentang benda dan juga indera penglihatannya tentang bentuk huruf dan bendanya.

Huruf hijaiyah merupakan huruf yang terdapat dalam Al-Quran, seperti hal nya huruf alphabet dalam bahasa Indonesia. Huruf itu lambang bunyi, begitu juga dengan huruf hujaiyah. Huruf hijaiyah terdiri dari dua kata yaitu huruf dan hijaiyah.

Huruf hijaiyah adalah abjad arab yang di mulai dari I (Alif) sampai dengan ي (ya), yang dibaca dari kiri ke kanan. Adapun arti huruf yaitu: Menurut bahasa artinya, mata tepi sesuatu, ujung. Menurut Istilah artinya, Suara yang berpegang/ tertekan kepada makhrajnya Surasman, O., (2002) mengemukakan bahwa huruf hijaiyah merupakan kunci dasar untuk mampu membca Al-Quran .

Huruf arab yang dapat dipahami secara sederhana adalah huruf yang terdiri dari lambang, makhraj dan sifat-sifat huruf. Makhraj huruf artinya tempat keluarnya suatu huruf yang diucapkan secara nyata, maka dengan adanya makhraj huruf ini dapat dibedakan huruf satu dengan huruf yang lainnya.
Sirojuddin (2000) menyatakan bahwa huruf hijaiyah adalah alfabeta Arab, yang disebut dengan huruf al hija (iyah) dan huruf al tahajji artinya huruf ejaan. Huruf hijaiyah digunakan sebagai ejaan untuk menulis kata atau kalimat dalam Al-Quran.

Huruf hijaiyah terdiri dari 30 jenis huruf. Jumlah tersebut termasuk hamzah dan lam alif. Jika dimaknai huruf alif sama dengan hamzah dan lam alif sama dengan lam. Berikut bentuk-bentuk huruf hijaiyah:

\begin{tabular}{|c|c|c|c|c|c|}
\hline$c_{\mathrm{Ha}}$ & $\frac{c}{\sin }$ & $\underset{T=n}{*}$ & $\underset{\mathrm{Ta}}{=}$ & بـ & $\begin{array}{c}1 \\
\text { Alif }\end{array}$ \\
\hline ص & $\begin{array}{l}j \\
z . a\end{array}$ & $\sum_{\text {Ro }}$ & $\begin{array}{c}3 \\
\text { Dzal }\end{array}$ & $\begin{array}{l}3 \\
\text { Dal }\end{array}$ & K̇ \\
\hline$\varepsilon$ & $\underset{D z 0}{5}$ & $\begin{array}{l}\text { b } \\
\text { Tho }\end{array}$ & ضُ & Shod & ث \\
\hline$\underset{\text { Mim }}{e}$ & $\underset{\text { Lam }}{J}$ & $\begin{array}{l}\text { s) } \\
\text { Kaf }\end{array}$ & Q قof & $\underbrace{}_{\mathrm{Fa}}$ & $\dot{\varepsilon}$ \\
\hline$\underset{\text { Yak }}{\text { Yak }}$ & $\begin{array}{c}\& \\
\text { Hamzah }\end{array}$ & $\frac{\searrow}{\text { Lam Alif }}$ & $\begin{array}{c}\infty \\
\text { Hha }\end{array}$ & $\begin{array}{c}9 \\
\text { wawa }\end{array}$ & $\underset{\text { Nun }}{\dot{0}}$ \\
\hline
\end{tabular}

Gambar 1. Huruf Hijaiyah

Secara umum tempat keluarnya huruf hijaiyah tersebut terdiri dari 5 tempat, yaitu: 1) Al-Jauf atau rongga mulut, yang terdiri dari 1 makhraj, 2) Al-Halq atau tenggorokan, terdiri dari 3 makhraj, 3) Al-Lisan atau lidah, terdiri dari 10 makhraj, 4) Asy-Syafatain atau dua bibir terdiri dari 2 makhraj. Dan e) $A l$ Khaisyum atau hidung terdiri dari 1 makhraj.

Agar kemampuan anak dalam mengenal huruf hijaiyah meningkat, maka guru diharapkan menggunakan strategi dalam pembelajarannya. Pemilihan penggunaan kartu huruf hijaiyah merupakan salah satu strategi yang tepat bila digunakan.

Kartu merupakan media yang berbasis visual. Dalam Kamus Besar Bahasa Indonesia (2012) kartu adalah kertas persegi panjang yang agak tebal untuk berbagai keperluan. 
Ada beberapa manfaat bermain kartu huruf hijaiyah bagi anak, yaitu: 1) menimbulkan kegembiraan. Kegembiraan bisa memicu prilaku positif lainnya yang dilakukan anak. 2) Sebagai sebuah rangsangan untuk anak melakukan kreatifitas. Anak yang sering melihat gambar-gambar yang menarik dan bernilai positif cenderung memiliki imajinasi baru dalam fikirannya. 3) Meningkatkan respon anak terhadap hal-hal baru. 4) Melatih anak menyelesaikan masalah atau mengatasi konflik. Ketika anak mendapati kesulitan dalam permainan kartunya, biasanya anak akan menyelesaikan sendiri kesulitan tersebut dengan kebiasaan bermain kartunya, hal ini akan berdampak pada kehidupan sehari-hari anak yang dapat menyelesaikan atau mengatasi konflik kecil dalam permainan yang lainnya. 5) Tempat untuk bersosialisasi dan melatih fungsi mental anak berfikir, berkhayal, mengingat atau menegakkan disiplin dengan mentaati peraturan dalam permainan. 6) Melatih kepekaan dan juga empati. Hal ini bisa terjadi karena anak bermain dengan lebih dari 2 anak. 7) Sarana untuk mengekspresikan perasaan. Anak yang peka akan mudah terbawa dalam suasana permainan, sehingga jika si anak merasa ada sesuatu yang salah dalam permainannya, maka ia langsung menyampaikannya.

Penggunaan kartu melalui gambargambar pada flas card pertama kali diperkenalkan oleh Glenn Doman, dengan cara mengelompokkan antara lain: seri bintang, seri buah-buahan, pakain, warna, bentuk bentuk angka, huruf-huruf hijaiyah dan sebagainya. Flas card umumnya terdiri dari gambar-gambar yang merupakan rangkaian pesan yang disajikan dengan mencantumkan keterangan pada setiap gambar.

Berdasarkan uraian di atas dapat kita menyimpulkan bahwa permainan kartu bergambar merupakan suatu bentuk aktivitas yang biasa dilakukan oleh beberapa anak dengan menggunakan kartu berbentuk persegi panjang yang diatas kartu tersebut terdapat gambar-gambar dan dilengkapi dengan katakata yang tujuannya untuk bermain sambil bersenang-senang sehingga diharapkan permainan ini membantu terbentuknya proses kepribadian anak agar tercapai perkembangan fisik, intelektual, sosial dan moral yang baik pada anak.

Begitu juga dalam pembelajaran $\mathrm{Al}$ Quran khususnya pada pengenalan hurufhuruf hijiyah juga dapat menggunakan kartu huruf hijaiyah. Penggunaan kartu huruf hijaiyah ini dapat menarik minat anak dalam membaca huruf hijaiyah. Maka diperlukan variasi dalam media kartu yang digunakan. Seperti huruf hijaiyah yang berwarna, jadi anak akan bersemangat disaat anak membaca huruf hijaiyah. Dengan demikian, anak mudah mengingat dan menjadi tidak malas setiap membaca huruf hijaiyah yang dipelajari.

Kemampuan membaca huruf hijaiyah di RA Arrahma sendiri belum berkembang dengan baik karena dari hasil wawancara awal peneliti dengan salah satu guru di RA tersebut menyebutkan persentase siswa yang telah mengenal huruf hijaiyah dengan langsung menggunakan metode Iqra belum maksimal. Dari jumlah siswa sebanyak 16 orang ada 12 orang yang belum bisa membaca huruf hijaiyah, dan bagi pihak sekolah ini merupakan pencapaian yang buruk dan memang harus ada evaluasi yang dilakukan. 
Berdasarkan uraian di atas maka peneliti tertarik untuk menindaklanjuti masalah tersebut dalam sebuah penelitian yang berjudul "Peningkatan Kemampuan Membaca Huruf Hijaiyah Melalui Kartu Huruf Hijaiyah Pada Anak Usia Dini Kelompok B2 di PAUD Arrahma Siak Hulu”.

\section{METODE PENELITIAN}

Penelitian yang digunakan dalam kegiatan ini merupakan Penelitian Tindakan Kelas (PTK). Penelitian Tindakan Kelas adalah penelitian tindakan (Classroom Action Research) yang dilaksanakan dengan tujuan memperbaiki mutu praktik di kelasnya (Arikunto, S., 2011).

Penelitian ini dilaksanakan di PAUD Arrahma yang berlokasi di Jalan. Garuda Perum Ginting 2 Kubang Jaya Kampar. Penelitian ini dilaksanakan selama 8 bulan.

Subjek dalam penelitian ini adalah keseluruhan siswa kelompok kelas B2 Kecamatan Kampar Kiri Hilir Kabupaten Kampar dengan jumlah 16 anak dengan rincian laki-laki 6 orang dan perempuan 9 orang. Seluruh siswa kelompok kelas B2 dijadikan subyek penelitian dengan pertimbangan karena jumlah siswa yang sedikit dan seluruh siswa belum pernah belajar membaca Al-Qur'an dengan menggunakan metode Muyassar.

Sementara objek dalam Penelitian ini adalah peningkatan kemampuan membaca huruf hijaiyah di PAUD Arrahmah Siak Hulu. Pengambilan data penelitian menggunakan teknik pengumpulan data tes, berupa: 1) Observasi. Observasi adalah suatu cara pengumpulan data dengan pengamatan langsung dan dicatat sistematis terhadap objek yang akan diteiliti. Observasi dilakukan oleh peneliti dengan cara pengamatan dan pencatatan mengenai pelaksanaan pembelajaran di kelas. Dalam penelitian ini observasi dilakukan untuk memperoleh data tentang pembelajaran mengenal huruf Hijaiyah.

2) Wawancara, wawancara dalam penelitian ini dilakukan terhadap guru dan peserta didik. Wawancara untuk mengungkap data yang sulit dicari/ditemukan pada saat observasi serta untuk mengetahui tanggapan peserta didik terhadap pelaksanaan pembelajaran mengenal huruf hijaiyah. 3) Dokumentasi. Metode dokumentasi dalam penelitian ini digunakan untuk memperoleh data tentang hasil belajar Al-Qur'an pada tahun yang lalu, sejarah singkat, letak geografis, visi misi, fasilitas sekolah, keadaan guru, karyawan, dan peserta didik. 4) Tes. Metode tes adalah alat lain yang digunakan untuk mengukur ketrampilan intelegensi, kemampuan dan bakat yang dimiliki oleh individu atau kelompok. Pada penelitian ini tes digunakan untuk mendapat jawaban yang bisa dijadikan dasar bagi penetapan skor angka.

Adapun proses analisis data selama di lapangan menggunakan lembar observasi dan analisis data setelah pelaksanaan penelitian dihitung secara kuantitatif dengan menggunakan persentase. Dalam menggunakan rumus persentase, dihitung dengan rumus persentase seperti dalam penilaian dengan persen yang banyak disebut percentages correction.

\section{HASIL DAN PEMBAHASAN}

Pada tahap awal dalam penelitian ini, peneliti sudah melakukan observasi secara sederhana di tempat penelitian dengan 
mengamati aktivitas siswa di PAUD Ar Rahmah di Jalan. Garuda Perum Ginting 2 blok B no 25 Kecamatan Siak Hulu Kampar. Observasi ini juga di ikuti dengan wawancara kepada guru dan kepala sekolah di PAUD Ar Rahma tersebut. Dari hasil observasi dan wawancara awal terlihat bahwa, aktivitas anak anak dalam mengenal huruf hijaiyah adalah dengan langsung menggunakan buku panduan Iqra tanpa menggunakan media belajar sebagai sarana belajar anak anak usia dini

Pada saat observasi ditemukan masalah diantaranya pada saat mengenalkan huruf hijaiyah pada siswa, anak langsung diperkenalkan dengan menggunakan buku Iqra sebagai media belajar, buku iqra merupakan buku yang biasa digunakan dalam pembelajaran Al quran pada anak-anak di TK Arrahma. Anak anak terlihat tidak tertarik dan tidak antusias dalam mengikuti kegiatan tersebut. Hasil wawancara dengan guru juga menyebutkan persentase siswa yang telah mengenal huruf hijaiyah dengan langsung menggunakan metode Iqra belum maksimal. Dari jumlah siswa sebanyak 16 orang ada 12 orang yang belum bisa membaca huruf hijaiyah, dan bagi pihak sekolah ini merupakan pencapaian yang buruk dan memang harus ada evaluasi yang dilakukan.

Pembahasan tentang penelitian ini, yaitu tentang "Peningkatan Kemampuan Membaca Huruf Hijaiyah Melalui Kartu Huruf Hijaiyah Pada Anak Usia Dini Kelompok B2 di PAUD Arrahma Siak Hulu”. Adapun hasil data yang diperoleh setelah dilakukan penelitian terurai pada penjelasan di bawah berikut ini :

\section{Deskripsi Data Penelitian}

Hasil penelitian ini memaparkan data kemampuan persentase klasikal anak agar kemampuan membaca huruf hijaiyah dengan menggunakan kartu huruf hijaiyah anak mengalami peningkatan.

Data hasil pembelajaran awal akan didahulukan untuk dipaparkan agar memudahkan penilaian dalam memahami kemajuan anak.

1. Data Siklus I Upaya peningkatan kemampuan membaca huruf hijaiyah dengan menggunakan kartu huruf hijaiyah. Pada Siswa Kelompok B2 TK PAUD Ar-Rahma, Kecamatan Siak Hulu.

Selanjutnya hasil data pelaksanaan perbaikan pembelajaran yang dilaksanakan dengan menempuh langkah-langkah pembelajaran yang dimulai dari persiapan sarana pendukung, penilaian siklus dan melakukan tes unjuk kerja. Dari hasil penilaian tersebut diperoleh data hasil penilaian dengan perolehan nilai tiap-tiap siswa pada siklus I, untuk lebih memahami maka bisa dilihat penjabaran di bawah ini.

Hasil penilaian yang dilakukan pada siklus I yakni diperoleh angka tertinggi 91 dengan frekuensi 2 atau (12.5\%) dan angka terendah yang di dapat adalah 49 dengan frekuensi $4(25 \%)$, dengan nilai rata-rata klasikal 50\%, siswa yang melaksanakan dengan selesai sebanyak 8 siswa $(50 \%)$, serta tidak melaksanakan dengan selesai sebanyak 8 siswa (50\%). Di bawah ini merupakan tabel distribusi data nilai berdasarkan hasil kemampuan siswa, Agar terlihat lebih jelas tersaji pada tabel 1 . 
Tabel 1

Distribusi Frekuensi Data Nilai Siklus I

\begin{tabular}{cccc}
\hline No & Interval & Frekuensi & Persentasi \\
\hline 1 & $33-52$ & 5 & $31.25 \%$ \\
\hline 2 & $53-72$ & 3 & $18.75 \%$ \\
\hline 3 & $73-92$ & 8 & $50 \%$ \\
\hline & & 16 & $100 \%$
\end{tabular}

Data Olahan Tahun 2019

Berdasarkan tabel di atas, dapat diperoleh data dengan interval penilaian siswa, yakni 5 siswa $(31.25 \%)$ dengan interval 33 - 52, 3 siswa $(18.75 \%)$ dengan dilihat pada grafik 1 . interval $53-72,8$ siswa (50\%) dengan interval 73 - 92. Untuk lebih jelas dapat dilihat pada grafik berikut:

Grafik 1

Hasil Tes Unjuk Kerja Siklus I

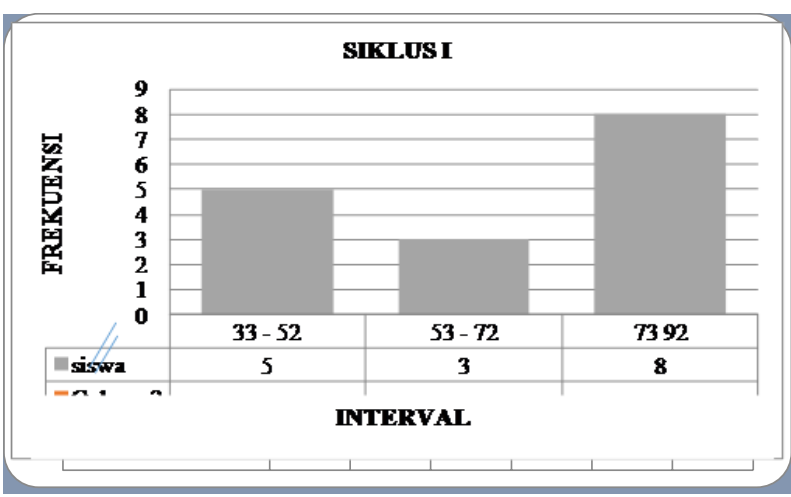

2. Data Siklus II Upaya Peningkatan kemampuan membaca huruf hijaiyah dengan menggunakan kartu huruf hijaiyah. Pada Siswa Kelompok B2 TK PAUD Ar Rahma, Kecamatan Siak Hulu.

Selanjutnya hasil data pelaksanaan perbaikan pembelajaran yang dilaksanakan dengan menempuh langkah-langkah pembelajaran yang dimulai dari persiapan sarana pendukung, dilakukan perencanaan siklus dan melakukan penilaian tes unjuk kerja. Dari hasil penilaian tersebut diperoleh data hasil penilaian dengan perolehan nilai tiap-tiap siswa pada siklus II, agar lebih jelas dapat dilihat dari penjabaran di bawah ini.

Dari hasil penilaian yang dilakukan pada siklus II yakni diperoleh nilai maksimal adalah 97 dengan frekuensi 2 atau (12.5\%) dan nilai minimal adalah 67 dengan frekuensi $1(6.25 \%)$, dengan rata-rata klasikal $93.75 \%$ dan yang tuntas sebanyak 15 siswa (93.75\%), serta tidak tuntas sebanyak 1 siswa $(6.25 \%)$. Di bawah ini merupakan tabel distribusi data nilai berdasarkan hasil kemampuan siswa, untuk lebih jelas dapat dilihat pada tabel 2.

Tabel 2:

Distribusi Frekuensi Data Hasil Siklus II

\begin{tabular}{cccc}
\hline No & Interval & Frekuensi & Persentase \\
\hline 1 & $33-47$ & 1 & 0 \\
\hline 2 & $48-62$ & 0 & 0 \\
\hline 3 & $63-77$ & 4 & $25 \%$ \\
\hline 4 & $78-92$ & 8 & $50 \%$ \\
\hline 5 & $93-107$ & 15 & $25 \%$ \\
\hline & & 16 & $100 \%$ \\
\hline
\end{tabular}

Olahan data tahun 2019

Berdasarkan tabel di atas, dapat diperoleh data dengan interval penilaian siswa yakni, 4 siswa (25\%) dengan interval $63-77$, 8 siswa (50\%) dengan interval $78-92,4$ siswa $(25 \%)$ dengan interval 93 - 107. Untuk lebih jelas dapat dilihat pada grafik 2 .

Grafik 2 :

Hasil Tes Unjuk Kerja Siklus II.

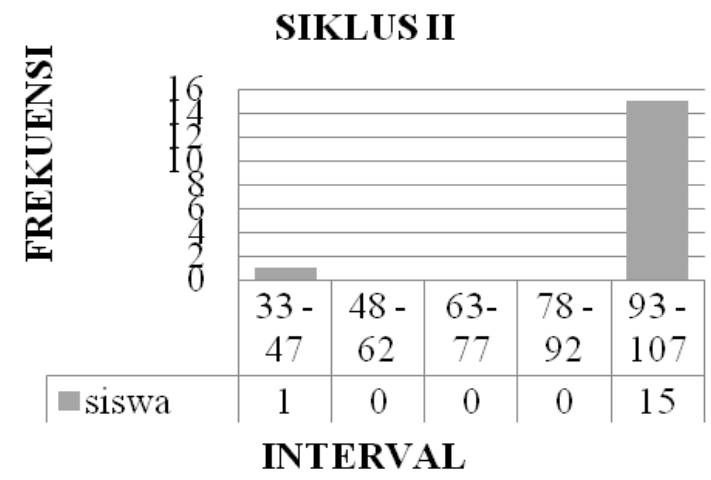


Berdasarkan data hasil pembelajaran, dimulai dari hasil data awal hingga melakukan perbaikan pembelajaran kesemua itu hasil pengamatan dan diskusi penulis dengan teman serta saran pihak-pihak yang ikut jalannya penelitian tindakan kelas ini, maka aktivitas siswa menjadi lebih aktif dan meningkatkan kemampuan membaca huruf hijaiyah pada anak PAUD di kelas B2 Arrahmah.

Untuk data siklus I menunjukan kategori tuntas terdapat 8 siswa atau (50\%), tidak tuntas sebanyak 8 siswa atau (50\%), sedangkan siklus II siswa yang tuntas sebanyak 15 siswa atau (93.75\%), dan tidak tuntas 1 siswa atau (6.25\%). Untuk lebih jelas mengenai peningkatan kemampuan membaca huruf hijaiyah pada anak usia dini, dapat dilihat keterangan pembelajaran siswa dalam menggunakan Kartu Huruf Hijaiyah dari data siklus I, dan siklus II pada tabel 5 di bawah ini:

Tabel 3:

Perbandingan Pembelajaran

\begin{tabular}{lccc|}
\hline \multicolumn{1}{c}{ Kategori } & Siklus I & Siklus II & \multicolumn{1}{c|}{ Ket } \\
\hline Tuntas & $8(50 \%)$ & $15(93.75 \%)$ & Adanya \\
Tidak Tuntas & $8(50 \%)$ & $1(6.25 \%)$ & peningkatan \\
\hline Jumlah & $16(100 \%)$ & $16(100 \%)$ & \\
\hline
\end{tabular}

Olahan data tahun 2019

Dari tabel di atas, dapat disimpulkan bahwa pada kegiatan siklus I siswa yang tuntas 8 orang, dan yang tidak tuntas 8 orang, dan siklus II siswa yang tuntas sebanyak 15 orang, dan tidak tuntas 1 orang, dengan metode menggunakan kartu huruf hijaiyah terdapat peningkatan dan jenjang siswa dalam upaya meningkatkan kemampuan membaca huruf hijaiyah pada anak usia dini dapat dilihat dari selisih peningkatan pembelajaran menggunakan metode kartu huruf hijaiyah pada grafik 3 .
Grafik 3:

Grafik Selisih Peningkatan.

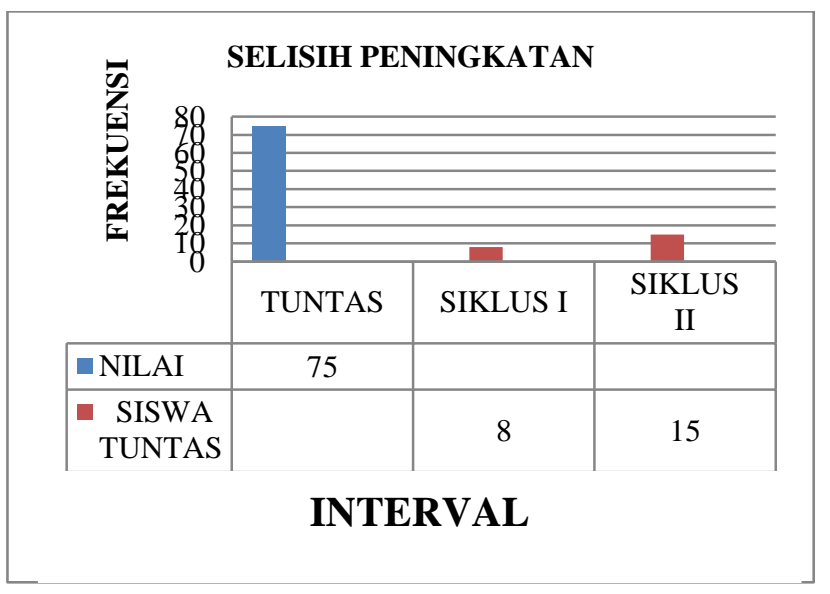

Dari grafik di atas, dapat diketahui bahwa indikator keberhasilan adalah 75, pencapaian siswa pada kegiatan siklus I sebesar 50\%, dan siklus II sebesar $93.75 \%$ maka pada siklus 1 menuju siklus 2 terjadi peningkatan yang signifikan.

\section{Pembahasan}

Berdasarkan dari data hasil penelitian, agar kemampuan membaca huruf hijaiyah di kelas B2 PAUD Arrahma Siak Hulu Kabupaten Kampar mengalami peningkatan maka dari hasil penilaian yang telah dilakukan pada siklus I yakni diperoleh angka maksimum adalah 91 dan angka minimum adalah 49, sedangkan siswa yang tuntas sebanyak 8 siswa (50\%), serta siswa yang tidak tuntas adalah 8 siswa $(50 \%)$.

Sedangkan yang terdapat pada siklus II yakni diperoleh nilai maksimum adalah 97 sedangkan nilai minimum adalah 67 , serta siswa tuntas dalam pelaksanaan sebanyak 15 siswa $(93.75 \%)$, serta siswa yang tidak tuntas ada 1 siswa (6.25\%). Dari hasil pembelajaran siklus II masih ada indikator yang rendah yaitu siswa belum baik untuk membaca 
dengan makharijal huruf hijaiyah, akan tetapi hasil pembelajaran telah mencapai $94 \%$. Untuk persentase secara keseluruhan pada siklus I yaitu $50 \%$, dan pada siklus II adalah $93 \%$.

Hasil penelitian ini memberikan dampak positif pada pembelajaran dengan metode baru pada anak-anak di TK Arrahma sehingga bisa dilanjutkan oleh guru-guru di TK Arrahma untuk pembelajaran Al Quran berikutnya.

\section{SIMPULAN}

Jika merujuk dari hasil penelitian yang telah dilaksanakan dan telah diuraikan dalam pembahasan maka dapat disimpulkan bahwa siswa kelas B2 PAUD Arrahma Siak Hulu Kabupaten Kampar dalam hal kemampuan membaca huruf hijaiyah dapat ditingkatkan lagi dengan media kartu huruf hijaiyah.

Hasil penelitian dapat dilihat dari meningkatnya kemampuan membaca huruf hijaiyah pada anak untuk kriteria baik pada setiap siklusnya yaitu dari siklus pra tindakan. Siklus I dan Siklus II. Hasil akhir pada Siklus I dan Siklus II menunjukkan indikator keberhasilan adalah 75, pencapaian siswa pada kegiatan siklus I sebesar 50\%, dan siklus II sebesar $93.75 \%$ maka pada siklus 1 menuju siklus 2 terjadi peningkatan yang signifikan.

Dari hasil pembelajaran siklus II masih ditemukan siswa yang belum baik untuk membaca dengan makharijal huruf hijaiyah, akan tetapi hasil pembelajaran telah mencapai $94 \%$.

Diharapkan penelitian ini bisa menjadi tambahan pengetahuan khususnya untuk siswa siswi TK Arrahma dan juga menjadi rujukan guru di TK Arrahma, maupun sekolah PAUD lainnya dalam pelaksanan pembelajaran Al Quran.

\section{DAFTAR PUSTAKA}

Anita, S. S., \& Pd, M. (2015). Perkembangan bahasa anak usia dini. Jurnal al-Shifa, 6(02).

Arikunto, S. (2011). Penilaian dan Penelitian Bidang Bimbingan dan Konseling. Yogyakarta: Aditya Media.

Departemen Pendidikan Nasional. (2012). Kamus Besar Bahasa Indonesia Pusat. Bahasa Edisi Keempat. Jakarta: Gramedia Pustaka Utama.

Dhieni, N. dkk, (2015). Metode pengembangan bahasa. Banten: Universitas Terbuka.

Iqromah, F. (2018). Identifikasi Kemampuan Anak Dalam Mengenal Huruf Hijaiyah di TK Se-Kecamatan Samigaluh Kulon Progo. Pendidikan Guru PAUD S-1, 7(1), 11-24.

Jamaris, M. (2006). Perkembangan dan pengembangan anak usia taman kanakkanak. Jakarta: Grasindo.

Musfiroh, T. (2009). Menumbuhkembangkan baca-tulis anak usia dini. Jakarta: Grasindo.

Rahmawati, R. (2013). Peningkatan Kemampuan Berbahasa Anak melalui Permainan Kartu Pesan Berantai di PAUD Melati Kota Padang. SPEKTRUM: Jurnal Pendidikan Luar Sekolah (PLS), 1(1), 74-87.

Sirojuddin, D. (2000). Seni Kaligrafi Islam. Bandung: PT. Remaja Rosdakarya.

Surasman, O. (2002). Metode Isani Kunci Praktis Membaca Al-Quran Baik dan Benar. Jakarta: Gema Isani Press.

Suryana, D. (2016). Pendidikan Anak Usia Dini: Stimulasi \& Aspek Perkembangan Anak. Prenada Media.

Suyanto, S., \& Novidha, F. (2008). Strategi pendidikan anak: pengenalan dengan matematika, sains, seni, bahasa, dan 
Al-Hikmah: Jurnal Agama dan Ilmu Pengetahuan

P-ISSN 1412-5382

Vol. 17 No. 1, April 2020

pengetahuan sosial. Yogyakarta:

Hikayat.

Yusuf, S. (2007). Psikologi Perkembangan Anak dan Remaja. Bandung: Rosdakarya. 